Article

\title{
Simulation of Hybrid Photovoltaic Solar Assisted Loop Heat Pipe/Heat Pump System
}

\author{
Nannan Dai ${ }^{1}$, Xinyi $\mathrm{Xu}^{1}{ }^{1}$, Shuhong $\mathrm{Li}^{1, *}$ and Zheng Zhang ${ }^{2}$ \\ 1 School of Energy and Environment, Southeast University, Nanjing 210000, China; \\ 15851865028@163.com (N.D.); ivesxy@foxmail.com (X.X.) \\ 2 Gemdale Properties and Investment Corporation Limited, Shanghai 200000, China; \\ zhangzheng3419@163.com \\ * Correspondence: equart@163.com; Tel.: +86-25-8379-2692
}

Academic Editor: Takahiko Miyazaki

Received: 10 December 2016; Accepted: 7 February 2017; Published: 16 February 2017

\begin{abstract}
A hybrid photovoltaic solar assisted loop heat pipe/heat pump (PV-SALHP/HP) water heater system has been developed and numerically studied. The system is the combination of loop heat pipe (LHP) mode and heat pump (HP) mode, and the two modes can be run separately or compositely according to the weather conditions. The performances of independent heat pump (HP) mode and hybrid loop heat pipe/heat pump (LHP/HP) mode were simulated and compared. Simulation results showed that on typical sunny days in spring or autumn, using LHP/HP mode could save $40.6 \%$ power consumption than HP mode. In addition, the optimal switchover from LHP mode to HP mode was analyzed in different weather conditions for energy saving and the all-year round operating performances of the system were also simulated. The simulation results showed that hybrid LHP/HP mode should be utilized to save electricity on sunny days from March to November and the system can rely on LHP mode alone without any power consumption in July and August. When solar radiation and ambient temperature are low in winter, HP mode should be used.
\end{abstract}

Keywords: solar energy; photovoltaic; heat pump; loop heat pipe; hybrid mode; simulation

\section{Introduction}

A photovoltaic/thermal $(\mathrm{PV} / \mathrm{T})$ hybrid solar system is a combination of a photovoltaic (PV) and solar thermal system which produces both electricity and heat from one integrated system. By cooling the PV module with a working fluid, the electricity yield can be improved and the heat pick up by the fluid can be used for space or water heating. Hence, the system becomes increasingly attractive in solar energy utilizations.

The concept of the PV/T was originally initiated by Kern and Russell in 1978 [1]. Soon after this, various PV/T systems or collectors for water heating have been theoretically and experimentally studied [2]. A PV/T system adopting a flat-box absorber design was constructed and tested by He et al. [3]. The results indicated that daily thermal efficiency could reach around 40\%. Ji et al. [4] simulated a hybrid PV/T system in residential buildings in Hong Kong. It was found that the fabric-integrated PV/T system could achieve a good electricity conversion and heat collecting efficiency. Herrando et al. [5] developed a model to estimate the performance of a hybrid PV/T system. It was concluded that the configuration of the PV/T system significantly affects its thermal and electrical output.

Using a heat pump, lower-grade heat energy extracted from a PV/T system could be upgraded to an appropriate temperature for heating purposes. One recent development in the integration of heat pump and photovoltaic technology lies in the use of photovoltaic solar assisted heat pump (PV-SAHP) systems [6-8]. Ito et al. [9] first proposed the conception of a solar-assisted heat pump system using 
a photovoltaic/thermal $(\mathrm{PV} / \mathrm{T})$ collector as its evaporator. The results indicated that a coefficient of performance (COP) of the heat pump as high as six could be obtained when the water temperature at the inlet of the condenser was at $40{ }^{\circ} \mathrm{C}$ in the daytime in winter. Recently, Ji et al. [10] experimentally investigated the dynamic performances of a PV-SAHP system. It was found that its thermal efficiency was $46 \%$ higher than a traditional air source heat pump. In addition, $\mathrm{Xu}$ et al. [11] numerically studied a PV/T heat pump system that had a modified collector/evaporator, and showed that this new system could efficiently generate electricity and thermal energy simultaneously both in Nanjing and Hong Kong all-year-round.

Although a PV-SAHP system is able to achieve a higher efficiency, the continuous operation of the compressor consumes considerable amounts of electricity when heating water. In order to cut down its power consumption, researchers combined a PV-SAHP system with a loop heat pipe (LHP) system in recent years. The LHP is a two-phase heat-transfer measure with the working fluid circulating in a loop, thus enabling remote and passive heat transfer at enhanced capacity. Due to its simple operation and environmental effect, LHP has been widely used in the thermal control of satellites and electronics [12-14] and it has gradually been gaining attention in the field of solar energy collection and transportation [15-17]. The LHP mode is passive, which means it does not consume work. Therefore, the hybrid photovoltaic solar assisted loop heat pipe/heat pump (PV-SALHP/HP) system could heavily reduce power consumption, raise the utilization ratio of solar energy, and promote energy saving.

For the hybrid PV-SALHP/HP system, the loop heat pipe (LHP) mode will be utilized when solar radiation is strong and the temperature of the working medium in the PVT evaporator is higher than that in the condenser. Correspondingly, the heat pump (HP) mode will be started when solar radiation is weak or the temperature difference of the working medium in the PV/T evaporator and the condenser cannot satisfy the condition of the LHP mode. Zhang et al. [18] designed a hybrid PV-SALHP/HP system and separate operation modes of the system were studied. The results showed that the thermal efficiency of the LHP system and HP system were respectively $35.55 \%$ and $74.49 \%$. However, the reasonable switchover of hybrid operation from LHP mode to HP mode was not analyzed. In addition, Zhang et al. [19] introduced a novel solar photovoltaic/loop-heat-pipe heat pump water heating system and provided a method to determine the characteristic parameters of the system.

Currently, the existing research of the hybrid PV-SALHP/HP system was confined to respective analysis of independent LHP mode and HP mode. However, it was worth mentioning that the optimal switchover of the hybrid mode could effectively save energy while heating water up to a desired temperature in a target amount time.

In this paper, a hybrid PV-SALHP/HP system has been developed and numerically studied. The loop heat pipe mode and heat pump mode can both operate independently or can switch to operate in a hybrid mode. A brief system description of the system is firstly presented. This is followed by a report on the development of a mathematical model for the PV-SALHP/HP system. As a novelty compared to existing work, a performance comparison of HP mode and hybrid LHP/HP mode was carried out and is reported. Then, on the basis of least power consumption, the effect on optimal switchover of LHP/HP mode was analyzed using various solar radiation and ambient temperature conditions. Finally, the all-year-round operating characteristics of the PV-SALHP/HP system were studied and are presented.

\section{System Description}

The schematic diagram of the hybrid PV-SALHP/HP system is shown in Figure 1, with the configuration details of its PV/T evaporator illustrated in Figure 2. The system is mainly composed of a PV/T evaporator, compressor, water tank with immersed condenser, and a thermostatic expansion valve. The PV/T evaporator is a flat-plate solar collector covering an area of $4 \mathrm{~m}^{2}$. From top to bottom, there are armored glass $(0.3 \mathrm{~mm})$, ethylene-vinyl acetate (EVA) film $(0.35 \mathrm{~mm})+$ silicon cells $(0.2 \mathrm{~mm})+$ EVA film $(0.35 \mathrm{~mm})+$ tedlar-polyester-tedlar (TPT) film $(0.3 \mathrm{~mm})$, aluminum sheet 
$(0.2 \mathrm{~mm})$, copper tubes, and insulating layer $(20 \mathrm{~mm})$. The space between each parallel copper tube is $120 \mathrm{~mm}$, the inner diameter of the tubes is $9 \mathrm{~mm}$, the compressor theoretical displacement is $0.4 \mathrm{~m}^{3} \cdot \mathrm{h}^{-1}$, and R134a is used as the refrigerant.

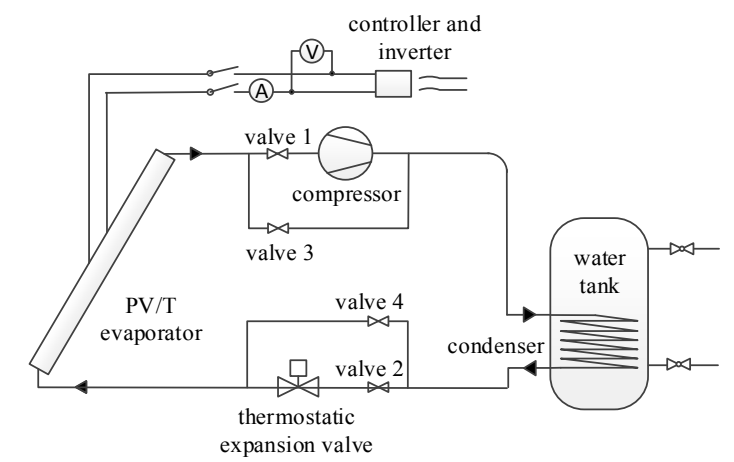

Figure 1. Schematic diagram of the photovoltaic solar assisted loop heat pipe/heat pump (PV-SALHP/HP) system.

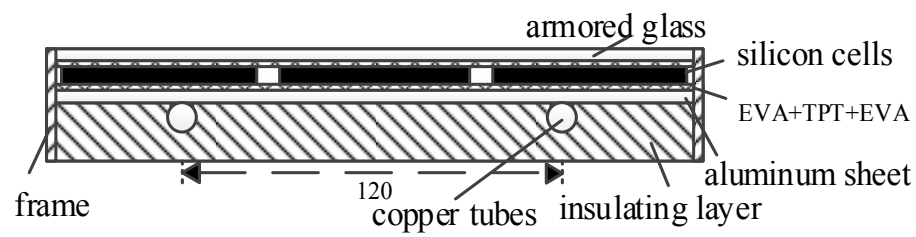

Figure 2. Structure diagram of the photovoltaic/thermal evaporator. EVA, ethylene-vinyl acetate; TPT, tedlar-polyester-tedlar.

Such a hybrid system can operate in three modes by controlling the valves. (1) Independent HP mode: by closing valve 3 and 4, and opening valve 1 and 2, the system produces hot water only in independent HP mode. The evaporated refrigerant in the collector will be compressed at a higher temperature. After transferring extra heat into the water tank, the condensed liquid flows throw the expansion valve and is sent back to the collector at a lower temperature; (2) Independent LHP mode: by closing valve 1 and 2, and opening valve 3 and 4, the system produces hot water only in independent LHP mode. The refrigerant absorbs heat and evaporated vapor transfers heat energy into the water tank directly, then the condensed refrigerant flows back to the PV/T evaporator according to gravity; (3) Hybrid LHP/HP mode: LHP mode will first be utilized when solar radiation is strong and the temperature of the working medium in the $\mathrm{PV} / \mathrm{T}$ evaporator is higher than that in the condenser. The system will be switched to HP mode when solar radiation is weak or the temperature difference of the working medium in the PV/T evaporator and the condenser cannot satisfy the condition of LHP mode. In this paper, independent HP mode and hybrid LHP/HP mode were compared.

\section{Model Development}

A mathematical model for the hybrid PV-SALHP/HP system has been established and used for evaluating its operating characteristics. Both HP mode and hybrid LHP/HP mode were numerically studied. A photovoltaic/thermal (PV/T) evaporator and condensing water tank could be used in HP mode as well as LHP mode, while an extra compressor model and throttle valve model were developed in the simulation of HP mode. It was assumed that the system operated at a steady-state condition within every time step in numerical simulation. 


\subsection{Model of LHP Mode}

The PV/T evaporator model and condensing water tank model were developed in the simulation of the LHP system.

\subsubsection{Model of PV/T Evaporator}

Heat transfer process of the PV/T collector is shown in Figure 3, with schematics of heat transfer illustrated in Figure 3a. After shining into PV cells, part of the sunlight was converted into electrical energy, part was lost to the external environment, and the rest was converted into heat energy absorbed by the refrigerant. In a steady-state condition, the PV/T evaporator's internal energy did not change with time, as such, the heat collected by collector per unit time can be calculated as follows:

$$
Q_{e}=Q_{s}-P_{p v}-\left(Q_{c o n}+Q_{r a d}\right)
$$

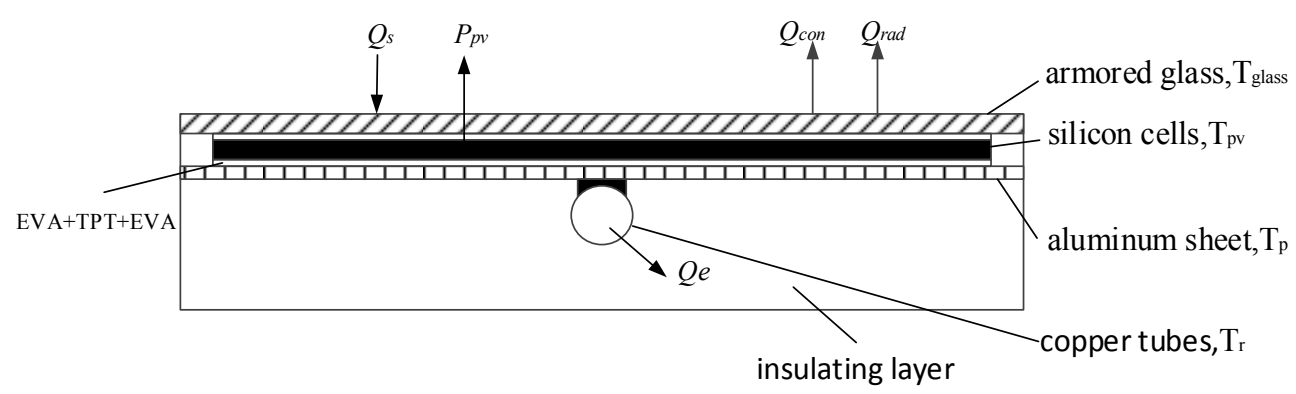

(a)

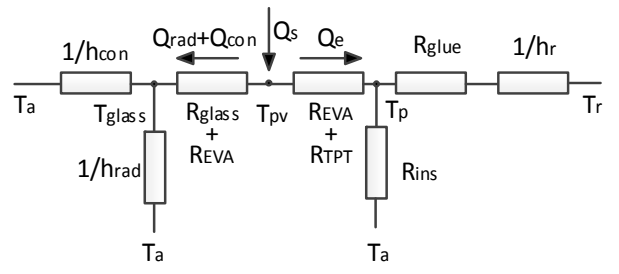

(b)

Figure 3. Heat transfer process of the photovoltaic/thermal (PV/T) collector. (a) Schematics of heat transfer in the PV/T collector; (b) Heat transfer resistance model of the PV/T collector.

$Q_{e}$ was further evaluated by using Equations (2) and (3) [20]:

$$
Q_{e}=E_{s} A_{p} \tau_{g}\left(\alpha-\beta \eta_{p v}\right)-U_{L} E_{s} A_{p}\left(T_{p v}-T_{a}\right)
$$

According to the heat transfer resistance model of the PV/T-collector shown in Figure 3b, the total heat loss coefficient between PV cells and environment, $U_{L}$, was defined by:

$$
U_{L}=\left(\frac{1}{h_{\text {con }}+h_{\text {rad }}}+R_{\text {glass }}+R_{E V A}\right)^{-1}
$$

where $R_{\text {glass }}$ and $R_{E V A}$ are the heat transfer resistances of armored glass and EVA film used in silicon cells, respectively. $h_{c o n}$ and $h_{\text {rad }}$ are the respective heat loss coefficients of the convective and radiation heat transfer between the surface of PV/T and ambient air, and can be evaluated by using Equations (4) and (5) [21], separately:

$$
\begin{gathered}
h_{c o n}=2.8+3.0 u_{w} \\
h_{r a d}=\varepsilon \sigma\left(T_{p v}{ }^{2}+T_{a}^{2}\right)\left(T_{p v}+T_{a}\right)
\end{gathered}
$$


As mentioned previously by many researchers, the performance of PV cells could deteriorate with increases in its working temperature. The dependences of crystalline silicon cells' electric efficiency, $\eta_{p v}$, was evaluated by Zondag et al. [22]:

$$
\eta_{\mathrm{pv}}=\eta_{0}\left[1-0.00045\left(t_{p \mathrm{v}}-25\right)\right]
$$

where $\eta_{0}$ is the electric efficiency of PV cells at standard conditions (i.e., $E_{s}=1000 \mathrm{~W} / \mathrm{m}^{2}, t_{p v}=25^{\circ} \mathrm{C}$ ).

In the PV/T evaporator, the refrigerant that absorbed heat from solar irradiation experienced changes of phase state. The heat transfer coefficient of two-phase region was calculated by Tong [23]:

$$
h_{t p}=3.4 X_{t t}^{-0.45} h_{l}
$$

where the heat transfer coefficient of liquid refrigerant was given by:

$$
h_{l}=0.023 R_{\mathrm{el}}^{0.8} p_{r}^{0.4} \frac{\lambda_{l}}{d}
$$

\subsubsection{Model of Condensing Water Tank}

An immersed condenser was used in the water storage tank. Assuming that the water temperature was uniform in the tank, and there was no heat loss from both the water tank and pipe to ambient air. $t_{w}$ represents the average temperature of the water inside the well mixed tank, so energy balance in refrigerant side was evaluated by:

$$
Q_{r}=m_{r}\left(h_{r 2}-h_{r 3}\right)=A_{c o n} U\left(t_{c o n}-t_{w}\right)
$$

The heat transfer coefficient between condenser and water, $U$, can be calculated according to the following equation:

$$
U=\frac{1}{\frac{A_{o}}{h_{c o n} A_{i}}+\frac{\delta_{m} A_{o}}{k_{m} A_{i}}+\frac{1}{h_{w}}}
$$

where $A_{o} / A_{i}$ is the ratio between the inside area and outside area of the condensing tube. $h_{c o n}$ and $h_{w}$ are the heat transfer coefficients of refrigerant side and water side, respectively. $\delta_{m}$ and $k_{m}$ are the thickness and thermal conductivity of condensing tube, respectively.

The energy balance in water side was evaluated by Jie et al. [24]:

$$
Q_{w}=M_{w} C_{p, w} \frac{d t_{w}}{d t}
$$

\subsection{Model of HP Mode}

Compared with the simulation of the LHP system, extra compressor model and throttle valve model were developed in the simulation of the HP system. The degree of sub cooling at the exit of condenser was $5^{\circ} \mathrm{C}$ and the pressure loss of the pipeline was ignored [11].

\subsubsection{Model of Compressor}

The refrigerant mass flow rate and input power of compressor were respectively calculated as follows:

$$
\begin{gathered}
m_{r}=\eta_{v} V_{h} \mathrm{r} / 60 v_{1} \\
N_{c o m}=m_{r}\left(h_{r 2}-h_{r 1}\right) / \eta
\end{gathered}
$$




\subsubsection{Model of Thermal Expansion Valve}

Assuming the inlet enthalpy and outlet enthalpy of thermal expansion value are equal.

$$
h_{r 3}=h_{r 4}
$$

\subsection{Performance Analysis Index}

In this simulation, here the performance index refers to the average calculated value within the whole period of operating time, which is from $t_{1}$ to $t_{2}\left(t_{1}\right.$ means the beginning time of the mode and $t_{2}$ means the ending time of the mode). For LHP mode and HP mode, definitions of the performance index are different, as follows.

\subsubsection{LHP Mode}

Based on the first law of thermodynamics, the overall photovoltaic/thermal efficiency of LHP mode, $\eta_{p v t}$, was defined by:

$$
\eta_{p v t}=\frac{\int_{t_{1}}^{t_{2}} q_{w} d t+\int_{t_{1}}^{t_{2}} p_{p v} d t}{\int_{t_{1}}^{t_{2}} A_{\mathrm{p}} E_{s} d t}=\eta_{t h}+\beta \eta_{p v}
$$

where thermal efficiency, $\eta_{t h}$, and electric efficiency, $\eta_{p v}$, were respectively calculated by:

$$
\begin{gathered}
\eta_{t h}=\int_{t_{1}}^{t_{2}} q_{w} d t / \int_{t_{1}}^{t_{2}} A_{\mathrm{p}} E_{s} d t \\
\eta_{p v}=\int_{t_{1}}^{t_{2}} p_{p v} d t / \int_{t_{1}}^{t_{2}} A_{p \mathrm{v}} E_{s} d t
\end{gathered}
$$

\subsubsection{HP Mode}

If $q_{w}$ is the condenser capacity and $w_{p}$ is the compressor power, the COP of the HP mode was calculated as follows:

$$
\mathrm{COP}=\frac{\int_{t_{1}}^{t_{2}} q_{w} d t}{\int_{t_{1}}^{t_{2}} w_{p} d t}
$$

The overall photovoltaic/thermal efficiency of HP mode, $\eta_{p v t}$, was defined by:

$$
\eta_{p v t}=\frac{\int_{t_{1}}^{t_{2}}\left(q_{w}+P_{\mathrm{pv}}\right) d t}{\int_{t_{1}}^{t_{2}}\left(w_{p}+A_{\mathrm{p}} E_{s}\right) d t}
$$

\section{Simulation Results and Discussion}

In order to verify the accuracy of the numerical simulation, the experiment parameters provided in the study by Zhang [25] were considered, as shown in Table 1. As shown in Table 2, the values of experiment and simulation were compared for HP model and LHP model, respectively. Experiments were conducted under six typical conditions, where solar radiation, ambient temperature, inlet water temperature, and outlet water temperature were included. The simulations were then conducted under the same conditions, so the heating time, heat energy, power consumption, and COP were compared, respectively. It can be seen from Table 2 that the maximum error is the heating time of HP model, which is at $4.5 \%$. Hence, the simulated values fit well with the experimental values and, as such, the mathematical model could be used to simulate the performance of the system further. 
Table 1. Numerical values of parameters used in experiment.

\begin{tabular}{cc}
\hline Component & Type and Main Parameters \\
\hline PV /T evaporator & $\begin{array}{c}\text { aluminum plate: } 780 \mathrm{~mm} \times 1270 \mathrm{~mm} \\
\text { copper tube: } 9.52 \mathrm{~mm} \text { (inner diameter) } \\
\text { insulating layer: } 50 \mathrm{~mm} \text { (thickness) }\end{array}$ \\
\hline compressor & $\begin{array}{c}\text { type: QD123Y } \\
\text { theoretic displacement: } 12.9 \mathrm{~cm}^{3} / \text { stoke }\end{array}$ \\
\hline throttle device & capillary: $2 \mathrm{~m}$ (length); $2 \mathrm{~mm}$ (innner diameter) \\
\hline condensing tank & volume: $150 \mathrm{~L}$ \\
\hline
\end{tabular}

Table 2. Comparison of simulation values and experimental values. HP, heat pump; LHP, heat pump; COP, coefficient of performance.

\begin{tabular}{|c|c|c|c|c|c|c|c|c|c|c|c|c|}
\hline \multirow{2}{*}{ HP } & \multirow{2}{*}{$\frac{E_{s}}{\mathrm{~W} / \mathrm{m}^{2}}$} & \multirow{2}{*}{$\frac{t_{a}}{{ }^{\circ} \mathrm{C}}$} & \multirow{2}{*}{$\frac{t_{w i}}{/^{\circ} \mathrm{C}}$} & \multirow{2}{*}{$\frac{t_{w o}}{/^{\circ} \mathrm{C}}$} & \multicolumn{2}{|c|}{$t / \mathrm{min}$} & \multicolumn{2}{|c|}{$Q_{w} / \mathbf{M J}$} & \multicolumn{2}{|c|}{$N_{\text {com }} / \mathrm{MJ}$} & \multicolumn{2}{|c|}{$C O P$} \\
\hline & & & & & $\exp$ & $\operatorname{sim}$ & $\exp$ & $\operatorname{sim}$ & $\exp$ & $\operatorname{sim}$ & $\exp$ & sim \\
\hline 1 & 686 & 35.2 & 30.4 & 54.1 & 200 & 209 & 14.89 & 14.28 & 3.86 & 3.71 & 3.79 & 3.85 \\
\hline 2 & 743 & 33.3 & 30.3 & 53.9 & 200 & 197 & 14.70 & 14.96 & 3.81 & 3.76 & 3.86 & 3.98 \\
\hline 3 & 699 & 36.1 & 30.4 & 54.2 & 200 & 202 & 14.97 & 14.83 & 3.85 & 3.79 & 3.89 & 3.94 \\
\hline error $/ \%$ & 1 & 1 & $\backslash$ & 1 & \multicolumn{2}{|c|}{4.5} & \multicolumn{2}{|c|}{4.1} & \multicolumn{2}{|c|}{3.8} & \multicolumn{2}{|c|}{3.1} \\
\hline \multirow{2}{*}{ LHP } & $E_{s}$ & $t_{a}$ & $t_{w i}$ & $t_{w o}$ & \multicolumn{2}{|c|}{$t / \mathrm{min}$} & \multicolumn{2}{|c|}{$Q_{w} / \mathrm{MJ}$} & \multicolumn{2}{|c|}{$\eta_{t h} / \%$} & \multicolumn{2}{|c|}{$\eta_{p v} / \%$} \\
\hline & $\mathrm{W} / \mathrm{m}^{2}$ & ${ }^{\circ} \mathrm{C}$ & ${ }^{\circ} \mathrm{C}$ & ${ }^{\circ} \mathrm{C}$ & $\exp$ & $\operatorname{sim}$ & $\exp$ & $\operatorname{sim}$ & $\exp$ & $\operatorname{sim}$ & $\exp$ & sim \\
\hline 4 & 630 & 37.7 & 31.4 & 47.7 & 420 & 418 & 10.3 & 10.59 & 37.36 & 36.9 & 9.23 & 9.32 \\
\hline 5 & 736 & 37.5 & 32.5 & 50.8 & 420 & 407 & 11.58 & 11.7 & 36 & 37.3 & 8.82 & 9.17 \\
\hline 6 & 741 & 37 & 32.3 & 51.3 & 420 & 404 & 11.93 & 11.74 & 36.97 & 37.5 & 9.37 & 9.06 \\
\hline error $/ \%$ & 1 & 1 & $\backslash$ & $\backslash$ & \multicolumn{2}{|c|}{3.8} & \multicolumn{2}{|c|}{2.8} & \multicolumn{2}{|c|}{3.6} & \multicolumn{2}{|c|}{3.7} \\
\hline
\end{tabular}

Using the mathematical models reported in Section 3, a performance comparison of PV-SAHP mode and hybrid PV-SALHP/HP mode was carried out. Then, on the basis of least power consumption, the effect on optimal switchover of LHP/HP mode was analyzed according to various solar radiation and ambient temperature conditions. In addition, the all-year-round operating characteristics of the PV-SALHP/HP system were studied.

\subsection{Comparison of HP Mode and LHP/HP Mode under Typical Weather Conditions}

The numerical values of parameters employed in the simulation are listed in Table 3.

Table 3. Numerical values of parameters used in simulation.

\begin{tabular}{cccccc}
\hline Parameter & Value & Unit & Parameter & Value & Unit \\
\hline$A_{p}$ & 4 & $\mathrm{~m}^{2}$ & $\beta$ & 0.86 & \\
$C_{p, w}$ & 4200 & $\mathrm{~J} /(\mathrm{kg} \cdot \mathrm{K})$ & $\delta_{\mathrm{m}}$ & 0.001 & $\mathrm{~m}$ \\
$d$ & 9 & $\mathrm{~mm}$ & $\varepsilon$ & 0.9 & \\
$k_{m}$ & 386 & $\mathrm{~W} / \mathrm{m} \cdot \mathrm{K})$ & $\eta_{0}$ & 0.097 & \\
$R_{\text {glass }}$ & 0.00356 & $\left(\mathrm{~m}^{2} \cdot \mathrm{K}\right) / \mathrm{W}$ & $\eta_{\mathrm{v}}$ & 0.65 & \\
$R_{E V A}$ & 0.00143 & $\left(\mathrm{~m}^{2} \cdot \mathrm{K}\right) / \mathrm{W}$ & $\sigma$ & $5.67 \times 10^{-8}$ & $\mathrm{~W} /\left(\mathrm{m}^{2} \cdot \mathrm{K}^{4}\right)$ \\
$V_{h}$ & 0.4 & $\mathrm{~m}^{3} / \mathrm{h}$ & $\tau_{\mathrm{g}}$ & 1.0 & \\
$\alpha$ & 0.9 & & & & \\
\hline
\end{tabular}

\subsubsection{On Sunny Days in Spring or Autumn}

The operating performances of independent HP and hybrid LHP/HP mode were simulated when the solar irradiation $E_{S}$ was assumed to be $600 \mathrm{~W} / \mathrm{m}^{2}$ and the ambient temperature $t_{a}$ was $15^{\circ} \mathrm{C}$. 
Figures 4 and 5 show the simulated operating performances for independent HP mode and hybrid LHP/HP mode on sunny days in spring or autumn. Independent LHP mode was not discussed here since the system would not work efficiently for the reason that the weather condition cannot satisfy this passive mode. Figure 4 illustrates that the independent HP mode would need only $195 \mathrm{~min}$ to heat water from $15{ }^{\circ} \mathrm{C}$ to $50{ }^{\circ} \mathrm{C}$, and the COP decreased from 6.1 at the beginning to 3.08 at the end of the heating process. While for hybrid LHP/HP mode, the total time of water heating was $360 \mathrm{~min}$. To make the most utilization of energy-saving LHP mode, the optimal water temperature at the moment of switching LHP mode to HP mode was $32.5^{\circ} \mathrm{C}$ by simulation. As a result, LHP mode was utilized for the first $260 \mathrm{~min}$, and then HP mode was started with an average COP at 3.51 for the following $100 \mathrm{~min}$. Because the water temperature was low at the beginning of the heating process, the compression ratio and electric consumption were both therefore lower, which resulted in a higher COP. With the water temperature rise, the working pressure difference of the compressor increased and the operation efficiency of the compressor decreased continuously, so the power consumption increased and COP dropped correspondingly.

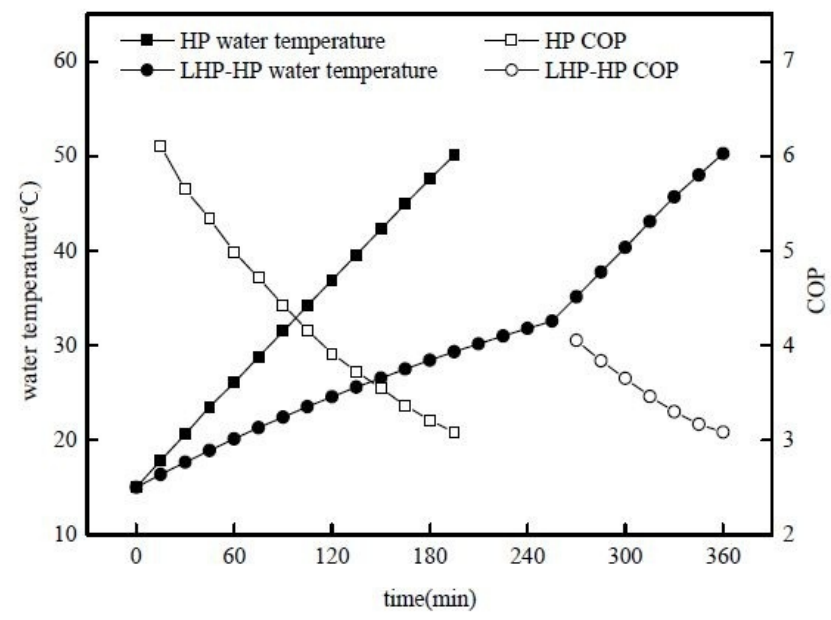

Figure 4. Variations of water temperature and COP with heating time for HP mode and LHP/HP mode.

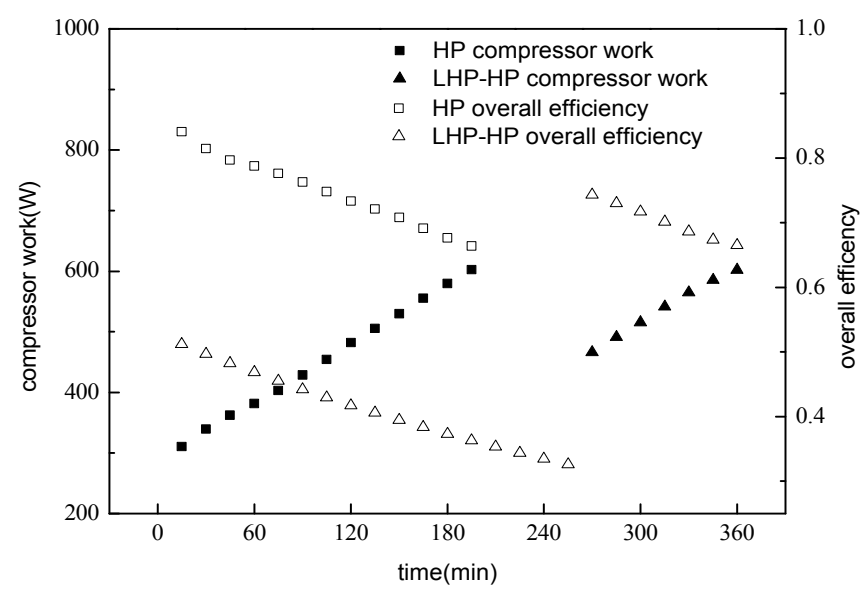

Figure 5. Variations of compressor work and overall efficiency with heating time for HP mode and LHP/HP mode.

As seen from Figure 5, for independent HP mode, the instantaneous compressor power consumption increased from $310 \mathrm{~W}$ to $598 \mathrm{~W}$, and the total power consumption was about $1.436 \mathrm{~kW} \cdot \mathrm{h}$ during the heating process. While for hybrid LHP-HP mode, the total power consumption was only about $0.853 \mathrm{~kW} \cdot \mathrm{h}$, saving $40.6 \%$ compressor power in comparison to the independent HP mode. 
In addition, for LHP/HP mode, the overall photovoltaic/thermal efficiency of LHP mode was 0.41, which was lower than the independent HP mode. This was because the overall photovoltaic/thermal efficiency was mostly influenced by the variation of thermal efficiency, and the thermal efficiency of LHP mode was much lower than that of HP mode due to their different heat transfer performances. While after switching to HP mode, the overall photovoltaic/thermal efficiency obviously enhanced up to 0.743 . The overall photovoltaic/thermal efficiency of the whole LHP/HP mode was about $33.7 \%$ lower than that of the independent HP mode.

\subsubsection{On Sunny Days in Winter}

In winter, there was just a small amount of refrigerant evaporating from the $\mathrm{PV} / \mathrm{T}$ evaporator because of the lower solar radiation and lower ambient temperature conditions. The driving force of LHP generated by the temperature difference between refrigerant and cooling water was not enough for persistent running. Therefore, only independent HP mode could be applied in winter conditions.

Figures 6 and 7 show the simulated operating characteristics on sunny days in winter, when the solar irradiation $E_{S}$ was assumed to be $350 \mathrm{~W} / \mathrm{m}^{2}$ and the ambient temperature $t_{a}$ was $5{ }^{\circ} \mathrm{C}$. It can be seen from Figure 6 that the independent HP mode would take approximately $329 \mathrm{~min}$ to heat water to $50{ }^{\circ} \mathrm{C}$. The COP of HP mode decreased from 5.2 to 2.48 during the heating process, and the average $\mathrm{COP}$ was at 3.44. From Figure 7, it was observed that the overall photovoltaic/thermal efficiency of HP mode decreased from 0.863 to 0.627 while the compressor power consumption continuously increased from $247.7 \mathrm{~W}$ to $494 \mathrm{~W}$. Under the typical winter conditions, the overall photovoltaic/thermal efficiency of HP mode was 0.744 and the total energy consumption was $2.04 \mathrm{~kW} \cdot \mathrm{h}$.

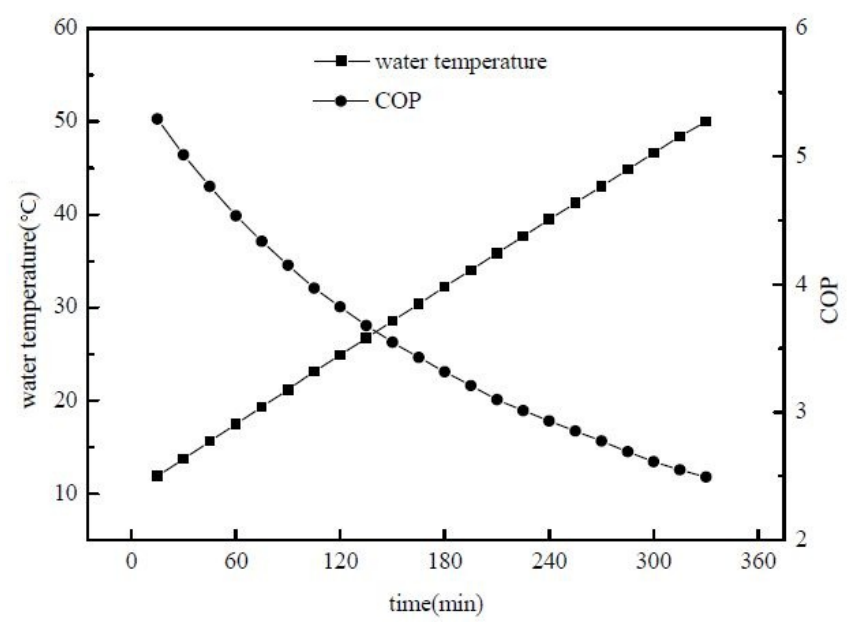

Figure 6. Variations of water temperature and COP with heating time for HP mode.

From the above, the overall efficiency of LHP/HP mode was lower than that of independent HP mode in spring or autumn. However, the hybrid LHP/HP mode is effectively energy-saving, so it should have top-priority for utilization in spring or autumn with abundant solar radiation. While in winter, when solar radiation is weak or the temperature difference of the working medium in the PV/T evaporator and condenser cannot satisfy the conditions of use for the loop heat pipe, LHP system was difficult to run efficiently. Therefore, the independent HP mode is the best choice for winter. 


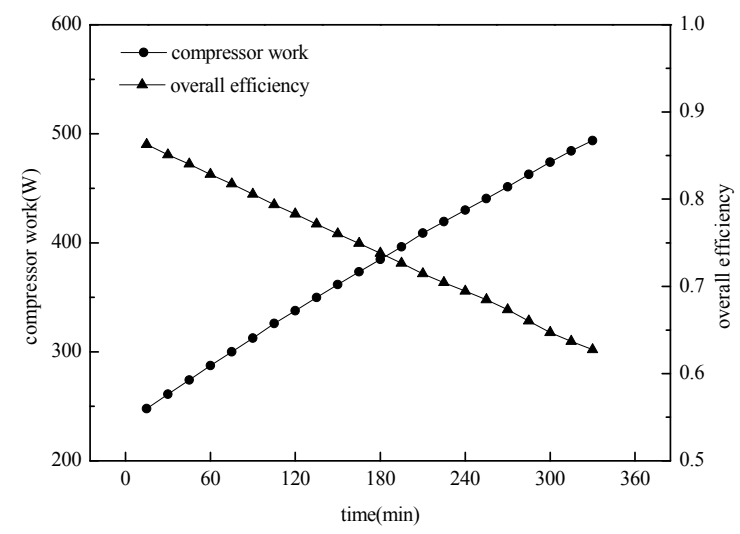

Figure 7. Variations of compressor work and overall efficiency with heating time for HP mode.

\subsection{Factors Affecting the Switchover from LHP Mode to HP Mode}

Solar irradiation and ambient temperature were the two main external factors influencing the operating performances of the PV-SALHP/HP system. In order to contrast the variations of operating performances with the two main factors, we assumed heating time to be the same under different conditions. Therefore, water was assumed to be heated within $360 \mathrm{~min}$ from $15{ }^{\circ} \mathrm{C}$ to $50{ }^{\circ} \mathrm{C}$. When using LHP/HP mode to make hot water within this limited time, it was necessary to choose a rational moment for switching LHP mode to HP mode based on the consideration of optimal energy savings.

In this model, the operating assumption was that the LHP/HP mode took $360 \mathrm{~min}$ in total to heat $150 \mathrm{~L}$ of water from $15^{\circ} \mathrm{C}$ to $50^{\circ} \mathrm{C}$. The water temperature when switching LHP mode to HP mode was considered to be a key parameter, representing the moment of switchover under the consideration of optimal energy savings. The simulated operation performances of LHP/HP mode under different solar irradiation and ambient temperature are shown in Figures 8 and 9. It can be observed that with the increase of solar irradiation and ambient temperature, LHP mode could be utilized for longer heating times because the temperature of the working medium in the PV/T evaporator was much higher than that in the condenser. Furthermore, the switching water temperature was higher and HP mode was utilized for a shorter heating time. Therefore, the compressor of HP mode consumed less power, as shown in Figure 9. In addition, COP of HP mode slightly increased with the increase of solar irradiation and ambient temperature. This result was owing to the fact that although the heat gain of evaporator increased with the increases of solar irradiation and ambient air temperature, the compressor power of HP mode also increased with the rising water temperature.

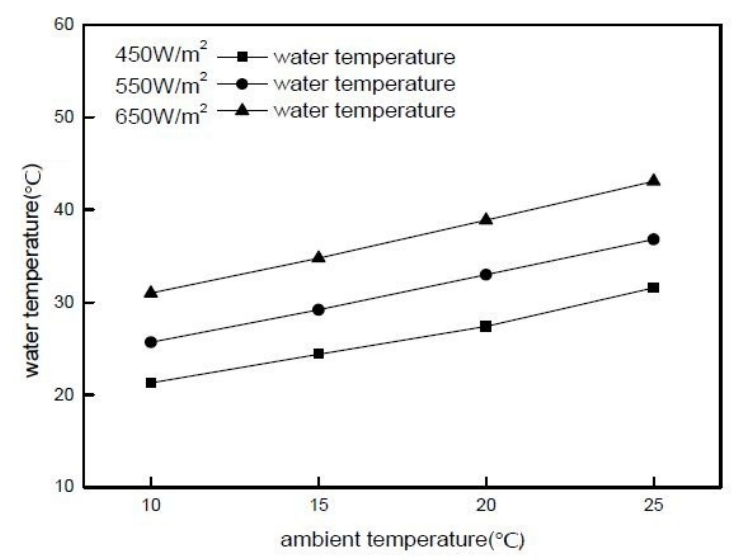

Figure 8. Variations of switching water temperature with weather conditions for LHP/HP mode. 


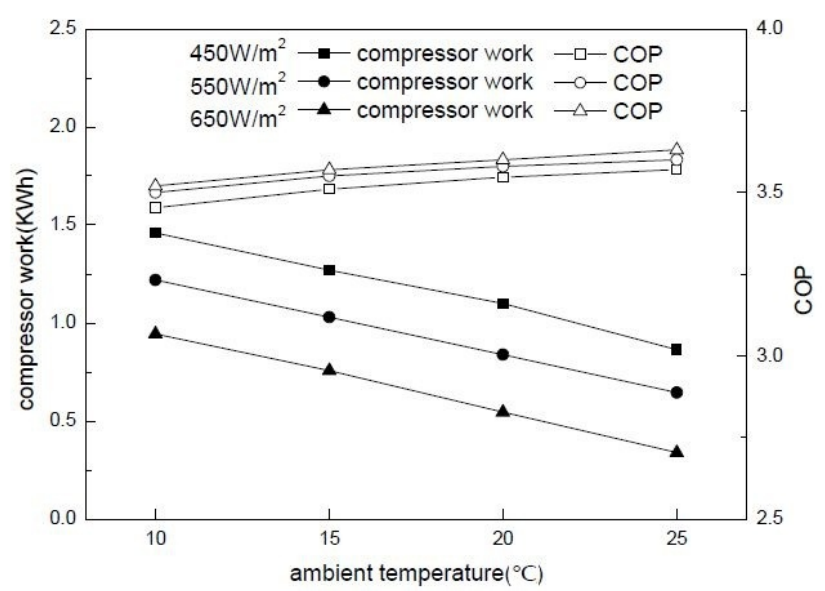

Figure 9. Variations of compressor work and COP with weather conditions for LHP/HP mode.

Therefore, with the increase in solar irradiation and ambient temperature, LHP mode should be prioritized as much as possible to save energy when solar irradiation and ambient temperature are high.

\subsection{Simulated All-Year Round Operating Performances of the PV-SALHP/HP System}

Nanjing has a typical summer-hot and winter-cold climate, requiring domestic hot water services all-year round. For different months, mean outdoor air temperature and mean total global solar radiation can range considerablly. In order to study the all-year round performance of the system, monthly simulation was studied in this section. As shown in Table 4, the monthly mean outdoor air temperature, $t_{a}$, can be as high as $28.6^{\circ} \mathrm{C}$ in summer and as low as $2.2^{\circ} \mathrm{C}$ in winter; the monthly mean total global solar radiation, $Q_{\text {solar }}$, ranges from $229.0 \mathrm{MJ} / \mathrm{m}^{2}$ (in December) to $485.0 \mathrm{MJ} / \mathrm{m}^{2}$ (in August). In Nanjing, the yearly total sunshine duration exceeds $2000 \mathrm{~h}$ [11]. Using the meteorological data of Nanjing and the mathematical model developed above, the all-year round performances of PV-SALHP/HP system operating in independent HP mode and hybrid LHP/HP mode are reported in this section.

Table 4. The simulated all-year-round operating characteristics of the system [26].

\begin{tabular}{ccccccccccccc}
\hline Month & Jan. & Feb. & Mar. & Apr. & May & June & July & Aug. & Sep. & Oct. & Nov. & Dec. \\
\hline$Q_{\text {solar }}\left(\mathrm{MJ} / \mathrm{m}^{2}\right)$ & 232.4 & 222.0 & 387.6 & 405.3 & 465.6 & 480.3 & 484.3 & 485.0 & 381.8 & 318.8 & 261.3 & 229.0 \\
$t_{a}\left({ }^{\circ} \mathrm{C}\right)$ & 2.2 & 4.5 & 8.9 & 15.7 & 20.6 & 24.8 & 28.6 & 27.7 & 23.5 & 16.9 & 10.5 & 4.9 \\
\hline
\end{tabular}

Assuming that the system was operated at the monthly mean outdoor air temperature and the monthly mean solar irradiation on sunny days. Figures 10 and 11 show the simulated monthly operating performances of the PV-SALHP/HP system when generating electricity and heating $150 \mathrm{~L}$ of water from $15{ }^{\circ} \mathrm{C}$ to $50^{\circ} \mathrm{C}$. As shown in Figure 10, from March to November, using independent $\mathrm{HP}$ mode consumed the highest energy consumption of $1.65 \mathrm{~kW} \cdot \mathrm{h}$ in November and the least energy consumption of $1.11 \mathrm{~kW} \cdot \mathrm{h}$ in July and August. While using hybrid LHP/HP mode, the highest energy consumption was $1.42 \mathrm{~kW} \cdot \mathrm{h}$ in November, $13.9 \%$ lower than that of HP mode. During July and August, LHP/HP mode could rely on LHP mode alone without any power consumption when heating water up to the targeted temperature. From Figure 11, the switching water temperature is the highest in July and August. The varied tendency of monthly mean photovoltaic/thermal efficiency when using independent HP mode was similar to the varied tendency of monthly mean solar irradiation. The monthly photovoltaic/thermal efficiency of HP mode varied from 0.697 to 0.776 , higher than that of the LHP/HP mode. 


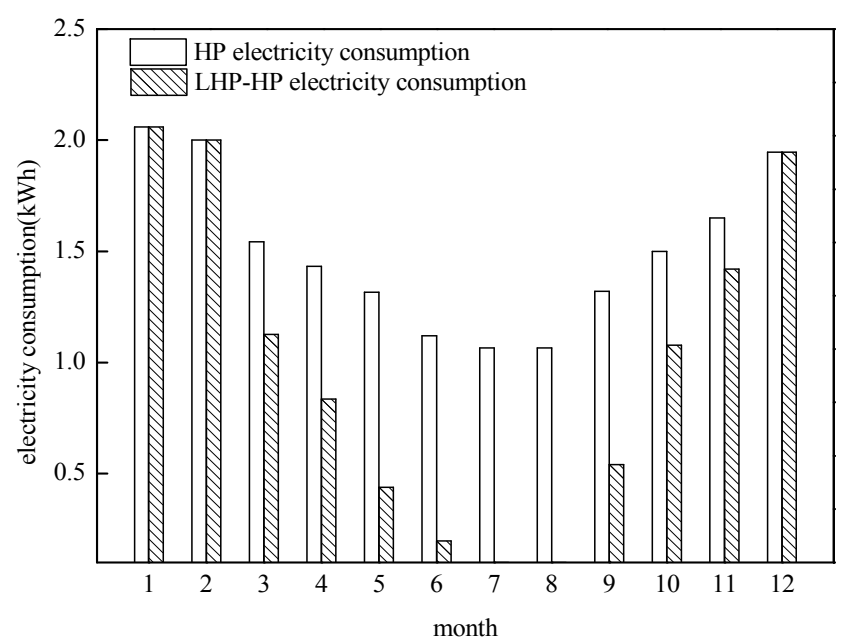

Figure 10. Monthly mean electricity consumption for HP mode and LHP/HP mode.

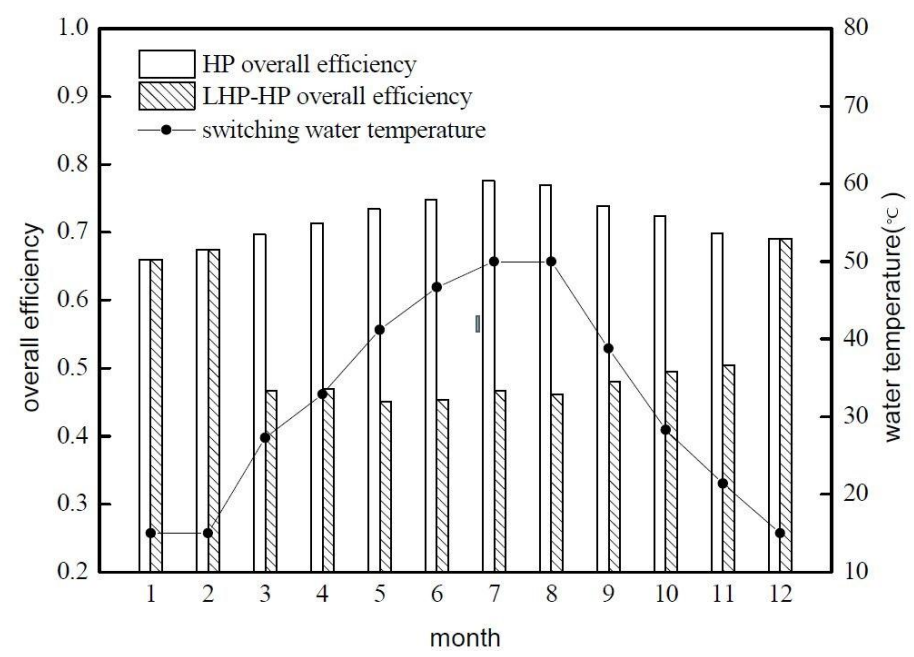

Figure 11. Monthly mean overall efficiency and switching water temperature for HP mode and LHP/HP mode.

Through the above analysis and comparison, it was shown that on sunny days during March to November, hybrid LHP/HP mode should be prioritized as much as possible to save power consumption effectively. Especially in July and August, such a hybrid mode could rely on LHP mode alone to make hot water without any power consumption.

\section{Conclusions}

1. During the heating of $150 \mathrm{~L}$ of water from $15{ }^{\circ} \mathrm{C}$ to $50{ }^{\circ} \mathrm{C}$ under typical sunny days in spring or autumn, the overall photovoltaic/thermal efficiency of hybrid LHP/HP mode was 0.496 and $33.7 \%$ lower than that of the independent HP mode, while the power consumed in the heating process of hybrid LHP/HP mode was $0.853 \mathrm{~kW} \cdot \mathrm{h}$, saving $40.6 \%$ of compressor power than independent HP mode. It can be seen that the LHP/HP mode should have top-priority to be utilized in spring or autumn with abundant solar radiation. While in winter, it was difficult to operate LHP mode persistently because of short sunshine duration and lower solar irradiation, therefore the independent HP mode is the best choice for winter.

2. Solar irradiation and ambient air temperature were the two main external factors influencing the operating performances of the hybrid LHP/HP mode. With an increase in solar irradiation and ambient temperature, the temperature of working medium in the PV/T evaporator was 
much higher than that in the condenser, so LHP mode could be utilized for a longer heating time. Therefore, the water temperature when switching LHP mode to HP mode was higher, so HP mode was utilized for a shorter heating time, resulting in less compressor power.

3. When using HP mode, the monthly mean photovoltaic/thermal efficiency varied from 0.697 to 0.776, which was higher in comparison to the LHP/HP mode, while the monthly mean power consumption of LHP/HP mode was apparently $13.9 \%$ less than that of HP mode. From March to November, hybrid LHP/HP mode should be prioritized to save energy. This hybrid mode could rely on LHP mode alone to make hot water without any power consumption especially in July and August.

Acknowledgments: The research has been supported by the National Science \& Technology Pillar Program of China during the Twelfth Five-year Plan Period (Projects 2014BAJ01B05) and the Industry-Academy-Research Forward-Looking Program of Jiangsu province (Projects BY2015070-14).

Author Contributions: Shuhong Li, Nannan Dai, Xinyi Xu, and Zheng Zhang conceived and designed the main analysis; Nannan Dai performed the numerical simulations and wrote the paper.

Conflicts of Interest: The authors declare no conflict of interest.

\section{Nomenclature}

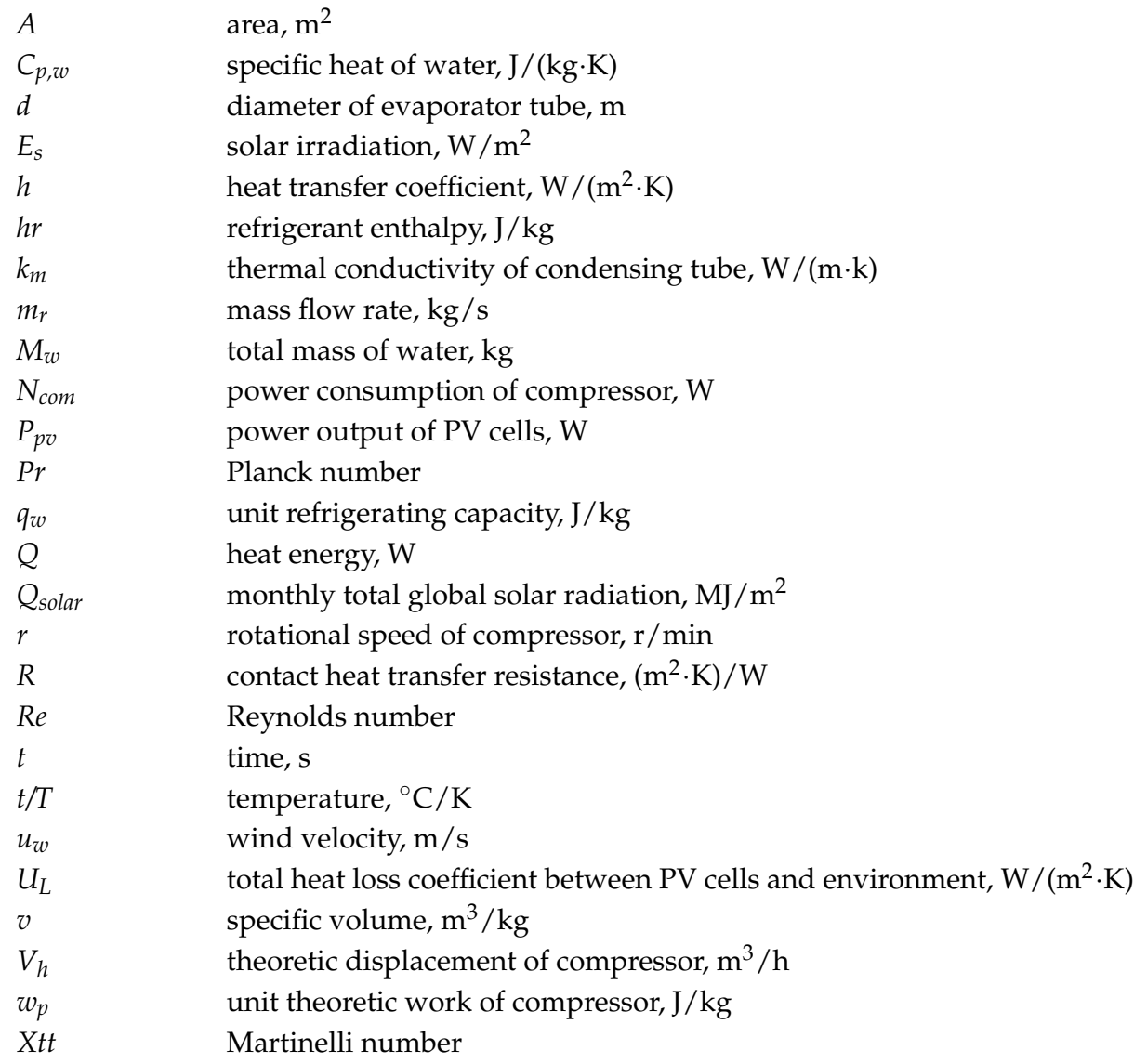

\section{Greek symbols}

absorptivity of PV cells heat transfer coefficient between the water and refrigerant, $\mathrm{W} /\left(\mathrm{m}^{2} \cdot \mathrm{K}\right)$ area rate of PV cells and collector thickness of condensing tube, $\mathrm{m}$ 


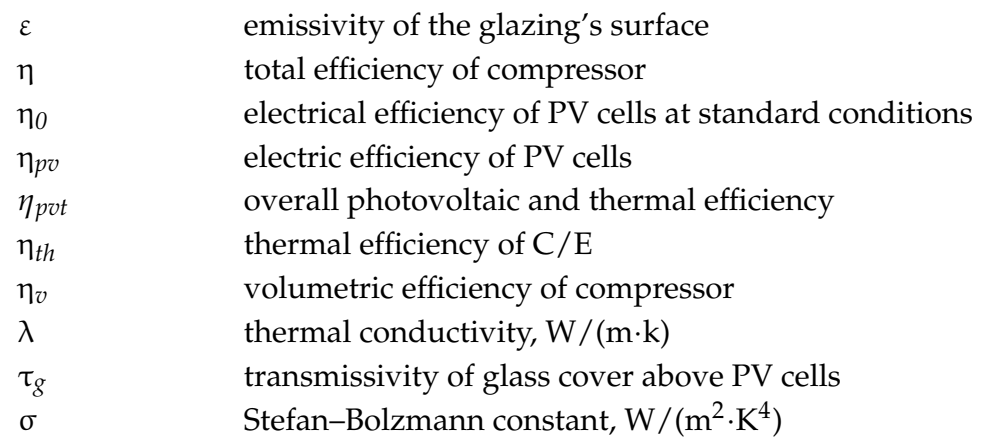

\section{Subscripts}

$\begin{array}{ll}a & \text { air } \\ \text { exp } & \text { experiment } \\ \text { com } & \text { compressor } \\ \text { con } & \text { convection/condenser } \\ e & \text { evaporator } \\ \text { EVA } & \text { EVA film } \\ \text { glass } & \text { glass cover } \\ \text { glue } & \text { silicon glue } \\ \text { ins } & \text { insulating layer } \\ l & \text { refrigerant liquid } \\ p & \text { PV/T evaporator } \\ p v & \text { PV cells } \\ p v t & \text { photovoltaic/thermal } \\ r & \text { refrigerant } \\ r a d & \text { radiation } \\ r_{1} & \text { state of refrigerant at compressor inlet in a heat pump cycle } \\ r_{2} & \text { state of refrigerant at compressor outlet in a heat pump cycle } \\ r_{3} & \text { state of refrigerant at condenser outlet in a heat pump cycle } \\ r_{4} & \text { state of refrigerant at evaporator inlet in a heat pump cycle } \\ s & \text { solar } \\ \text { sim } & \text { simulation } \\ t h & \text { thermal } \\ t p & \text { two-phase region } \\ w & \text { water } \\ w i & \text { inlet water } \\ w o & \text { outlet water } \\ & \end{array}$

\section{Abbreviations}

$\begin{array}{ll}\text { COP } & \text { coefficient of performance } \\ \text { EVA } & \text { ethylene-vinyl acetate } \\ \text { HP } & \text { heat pump } \\ \text { LHP } & \text { loop heat pipe } \\ \text { LHP/HP } & \text { hybrid loop heat pipe/heat pump } \\ \text { TPT } & \text { tedlar-polyester-tedlar }\end{array}$

\section{References}

1. Kern, E.C.; Russell, M.C. Combined photovoltaic and thermal hybrid collector systems. In Proceedings of the 13th IEEE Photovoltaic Specialists Conference, Washington, DC, USA, 5 June 1978; pp. 1153-1157.

2. Chow, T.T. A review on photovoltaic/thermal hybrid solar technology. Appl. Energy 2009, 87, 365-379. 
3. He, W.; Chow, T.T.; Ji, J.; Lu, J.; Pei, G.; Chan, L.S. Hybrid photovoltaic and thermal solar-collector designed for natural circulation of water. Appl. Energy 2006, 83, 199-210. [CrossRef]

4. Ji, J.; Chow, T.T.; He, W. Dynamic performance of hybrid photovoltaic/thermal collector wall in Hong Kong. Build. Environ. 2003, 38, 1327-1334. [CrossRef]

5. Herrando, M.; Markides, C.N.; Hellgardt, K. A UK-based assessment of hybrid PV and solar-thermal systems for domestic heating and power: System performance. Appl. Energy 2014, 122, 288-309. [CrossRef]

6. Shihabudheen, M.; Arun, P. Performance evaluation of a hybrid photovoltaic-thermal water heating system. Int. J. Green Energy 2014, 11, 969-986. [CrossRef]

7. Huang, B.J.; Lin, T.H.; Hung, W.C.; Sun, F.S. Performance evaluation of solar photovoltaic/thermal systems. Sol. Energy 2001, 70, 443-448. [CrossRef]

8. Badescu, V. First and second law analysis of a solar assisted heat pump based heating system. Energy Convers. Manag. 2002, 43, 2539-2552. [CrossRef]

9. Ito, S.; Miura, N.; Wang, J.Q.; Nishikawa, M. Heat pump using a solar collector with photovoltaic modules on the surface. J. Sol. Energy Eng. 1997, 119, 147-151. [CrossRef]

10. Ji, J.; He, H.; Chow, T.; Pei, G.; He, W.; Liu, K. Distributed dynamic modeling and experimental study of PV evaporator in a PV/T solar-assisted heat pump. Int. J. Heat Mass Transf. 2009, 52, 1365-1373. [CrossRef]

11. Xu, G.; Deng, S.; Zhang, X.; Yang, L.; Zhang, Y. Simulation of a photovoltaic/thermal heat pump system having a modified collector/evaporator. Sol. Energy 2009, 83, 1967-1976. [CrossRef]

12. Vasiliev, L.L. Heat pipe in modern heat exchangers. Appl. Therm. Eng. 2005, 25, 1-19. [CrossRef]

13. Li, J.; Wang, D.; Peterson, G.P. Experimental studies on a high performance compact loop heat pipe with a square flat evaporator. Appl. Therm. Eng. 2010, 30, 741-752. [CrossRef]

14. Li, J.; Tian, W.; Lv, L. A thermosyphon heat pipe cooler for high power leds cooling. Heat Mass Transf. 2016, 52, 1541-1548. [CrossRef]

15. Zhao, X.; Wang, Z.; Tang, Q. Theoretical investigation of the performance of a novel loop heat pipe solar water heating system for use in Beijing, China. Appl. Therm. Eng. 2010, 30, 2526-2536. [CrossRef]

16. Wu, S.Y.; Zhang, Q.L.; Xiao, L.; Guo, F.H. A heat pipe photovoltaic/thermal (PV/T) hybrid system and its performance evaluation. Energy Build. 2011, 43, 3558-3567. [CrossRef]

17. Huang, B.J.; Lee, J.P.; Chyng, J.P. Heat-pipe enhanced solar-assisted heat pump water heater. Sol. Energy 2004, 78, 375-381. [CrossRef]

18. Zhang, L.; Pei, G.; Zhang, T.; Ji, J. A new photovoltaic solar-assisted loop heat pipe/heat-pump system. CIESC J. 2014, 65, 3228-3236.

19. Zhang, X.; Zhao, X.; Xu, J.; Yu, X. Characterization of a solar photovoltaic/loop-heat-pipe heat pump water heating system. Appl. Energy 2012, 102, 1229-1245. [CrossRef]

20. $\mathrm{Xu}, \mathrm{G}$. Theoretical and Experimental Study of solar Photovoltaic/Thermal Integrated Heat Pump System. Ph.D. Thesis, Southeast University, Nanjing, China, 2012.

21. Kuang, Y.H.; Sumathy, K.; Wang, R.Z. Study on a direct-expansion solar-assisted heat pump water heating system. Int. J. Energy Res. 2003, 27, 531-548. [CrossRef]

22. Zondag, H.A.; Vries, D.W.D.; Helden, W.G.J.V.; Zolingen, R.J.C.V.; Steenhoven, A.A.V. The yield of different combined PV-thermal collector designs. Sol. Energy 2003, 74, 253-269. [CrossRef]

23. Tong, L.S. Boiling Heat Transfer and Two-Phase Flow; Taylor \& Francis: Abingdon, UK, 1997.

24. Jie, J.I.; Huide, F.U.; Hanfeng, H.E.; Pei, G. Performance analysis of an air-source heat pump using an immersed water condenser. Front. Energy 2010, 4, 234-245. [CrossRef]

25. Zhang, L. Experimental Study of a Photovoltaic Solar-Assisted Loop Heat Pipe/Heat Pump System. Ph.D. Thesis, University of Science and Technology, Hefei, China, 2014.

26. Central Weather Bureau. 2008. Available online: http://www.nmc.gov.cn/ (accessed on 2 February 2015).

(C) 2017 by the authors; licensee MDPI, Basel, Switzerland. This article is an open access article distributed under the terms and conditions of the Creative Commons Attribution (CC BY) license (http:/ / creativecommons.org/licenses/by/4.0/). 